\title{
PENGARUH KUALITAS PELAYANAN TERHADAP KEPUASAN PEDAGANG PADA PENGELOLAAN KSU PUSAT GROSIR BUTUNG DI KOTA MAKASSAR
}

\author{
Sumarsih \\ Sumarsihrasyid2@gmail.com \\ (Dosen Universitas Sulawesi Barat)
}

\section{PENDAHULUAN}

\section{Latar Belakang}

Pasar Butung adalah pusat grosir terbesar di Kota Makassar Propinsi Sulawesi Selatan, dan Kawasan Timur Indonesia. Pasar ini juga menjadi sentra kulakan pakaian jadi para pedagang dari Kawasan Timur Indonesia. Barang-barang yang dijual di Pusat Grosir Butung berasal dari Tanah Abang (Jakarta) dan Pasar Turi Surabaya (Jawa Timur). Pedagang kecil di Pasar Butung rata-rata memiliki omzet sekitar Rp 10 juta per hari. Asumsinya, harga setiap los dan toko Rp 200 juta hingga Rp 500 juta berdasarkan barangbarang yang ada di dalamnya, maka bisa diperkirakan omzet pedagang besar di pasar yang berdiri sejak tahun 1912 ini. Omzet atau perputaran uang di pasar ini bisa mencapai Rp 9 miliar per hari (Pengelolaan Pusat Grosir Butung, 2012).

Pengelolaanan pasar Butung berada di bawah naungan pemerintah Kota Makassar melalui Perusahaan Daerah (PD) Pasar Makassar Raya. Namun dalam pelaksanaannya, pemerintah mengikutserkatan pengusaha besar dalam mengelola Pasar Butung.

Pengelolaan KSU Pusat Grosir Butung di Kota Makassar dapat meningkatkan mutu pelayanan masyarakat yang berorientasi pada kepuasan pedagang serta merubah image buruk masyarakat terhadap pelayanan KSU menjadi lebih baik. Implementasi sistem manajemen mutu (ISO 9001:2000) menjadikan pelayanan menjadi lebih baik, semua kegiatan dilakukan secara prosedural, terdokumentasi dan secara rutin dapat dilakukan analisis terhadap kegiatan yang telah dilakukan. Meskipun demikian, Standar mutu pelayanan ISO 9001:2000 belum dapat menjamin kebutuhan pedagang akan pelayanan yang sesuai harapan/keinginannya.

Pengelolaan KSU Pusat Grosir Butung Makassar memiliki jumlah anggota yang meningkat setiap tahun. Meskipun pedagang di Pasar Butung tidak semuanya menjadi anggota KSU, namun perubahan selama pasca kebakaran yang dulunya tradisional sekarang berubah menjadi modern dengan mengalami peningkatan kualitas yang cukup signifikan. Adapun data jumlah pedagang dan Anggota KSU di Pusat Grosir Butung Kota Makassar, dapat dilihat pada Tabel 1.

Tabel 1. Jumlah Pedagang dan Anggota KSU di Pusat Grosir Butung Kota Makassar Tahun 2012

\begin{tabular}{|c|c|c|c|}
\hline No. & Tahun & $\begin{array}{c}\text { Jumlah Pedagang } \\
\text { (orang) }\end{array}$ & $\begin{array}{c}\text { Jumlah Anggota KSU } \\
\text { (orang) }\end{array}$ \\
\hline 1. & 2008 & 380 & 221 \\
2. & 2009 & 450 & 276 \\
3. & 2010 & 650 & 442 \\
4. & 2011 & 725 & 543 \\
5. & 2012 & 800 & 644 \\
\hline \multicolumn{2}{|c|}{ Rata-rata } & 601 & 425 \\
\hline
\end{tabular}


Sumber: Kantor Pengelolaan KSU Pusat Grosir Butung, 2013

Berdasarkan data pada Tabel 1 dapat dijelaskan perkembangan jumlah pedagang dan anggota KSU di Pusat Grosir Butung Kota Makassar mengalami peningkatan setiap tahun selama 2008 sampai dengan 2012, yakni pada tahun 2008 jumlah anggota KSU 221 orang dari total pedagang sebanyak 380 orang dan meningkat terus hingga tahun 2012 yang mencapai jumlah anggota KSU sebanyak 644 orang dari seluruh pedagang sebanyak 800 orang. Dengan demikian, rata-rata peningkatan jumlah anggota KSU adalah 425 orang dari rata-rata jumlah pedagang 601 orang atau dapat dikatakan perbandingan jumlah anggota KSU terhadap jumlah pedagang di Pasar Grosir Butung adalah sebesar 71 persen. Hal ini mengindikasikan masih rendahnya kepuasan pedagang karena masih ada pedagang yang belum menjadi anggota KSU Pusat Grosir Butung. Oleh karena itu, perlu upaya meningkatan kepuasan pedagang sebagai anggota KSU dengan memberikan pelayanan yang memuaskan kepada semua pedagang di Pusat Grosir Butung. Permasalahan ketidakpuasan pedagang dengan pelayanan yang diberikan oleh Pengelolaan KSU Pusat Grosir Butung perlu dikaji karena kualitas pelayanan KSU sangat diperlukan pedagang sebagai anggota KSU dalam rangka memenuhi kebutuhan dan keinginan yang terkait dengan pengembangan usaha serta peningkatan pendapatannya.

Konsep ini memformulasikan 5 dimensi, yaitu: dimensi tangibles (tampilan fisik), reliability (kehandalan), responsiveness (ketanggapan), assurance (jaminan) dan empathy (empati). Tangibles meliputi fasilitas fisik, perlengkapan, dan sarana komunikasi. Reliability yaitu kemampuan perusahaan untuk memberikan pelayanan yang dijanjikan dengan tepat waktu dan memuaskan. Responsiveness yaitu kemampuan para staf untuk membantu para pelanggan dan memberikan pelayanan dengan tanggap. Assurance mencakup kemampuan, kesopanan dan sifat dapat dipercaya yang dimiliki para staf, bebas dari bahaya, resiko atau keragu-raguan. Dan terakhir Emphaty, mencakup kemudahan dalam melakukan hubungan komunikasi yang baik dan memahami kebutuhan para pelanggan (Parasuraman dan Zeithaml, 1990). Kelima dimensi kualitas pelayanan tersebut dapat pula diterapkan pada pelayanan KSU guna meningkatkan kepuasan pedagang di Pusat Grosir Butung di Kota Makassar.

Berdasarkan pengamatan penulis bahwa pelayanan yang diterima pedagang pada Pengelolaan KSU Pusat Grosir Butung di Kota Makassar masih kurang maksimal. Hal ini dapat dilihat dari beberapa pedagang yang masih banyak mengeluhkan pelayanan yang lamban dari petugas termasuk penyelesaian administrasi bagi pedagang, begitu pula perilaku petugas yang kurang ramah dan kurang komunikatif terhadap pedagang menyebabkan pedagang merasa kurang nyaman. Selain itu, kondisi lingkungan fisik juga kurang mendukung seperti tempat parkir yang masih belum teratur sehingga dapat mengganggu kenyamanan dan keamanan kendaraan pedagang. Hal ini berarti bahwa kualitas pelayanan khususnya pada pedagang di Pusat Grosir Butung belum memadai, sehingga kelima dimensi kualitas pelayanan yang dikembangkan Parasuraman, Berry dan Zeitham tersebut perlu dikaji melalui penelitian ini guna meningkatkan kepuasan pedagang pada Pengelolaan KSU Pusat Grosir Butung di Kota Makassar.

Apabila kinerja pengelolaan KSU dalam hal ini kualitas pelayanan di bawah harapan, maka pedagang akan kecewa. Bila kinerja sesuai dengan harapan, pedagang akan puas. Sedangkan bila kinerja melebihi harapan, pedagang akan sangat puas. Harapan pedagang dapat dibentuk oleh pengalaman masa lampau, dan komentar dari kerabatnya. Oleh karena itu, Pengelolaan KSU Pusat Grosir Butung Kota Makassar perlu 
memperhatikan permasalahan yang sedang dihadapi pedagang terkait dengan dimensi kualitas pelayanan, serta perlu melakukan pemantauan dan pengukuran terhadap kepuasan pedagang sebagai anggota KSU karena hal ini telah menjadi hal yang esensial bagi pengelolaan KSU Pusat Grosir Pasar Butung. Dengan demikian, langkah tersebut dapat memberikan umpan balik dan masukan bagi keperluan pengembangan dan implementasi strategi peningkatan kepuasan pedagang di Pasar Butung Makassar.

Berdasarkan uraian tersebut di atas, maka penulis tertarik untuk melakukan penelitian, yang berjudul: "Pengaruh Kualitas Pelayanan Terhadap Kepuasan Pedagang pada Pengelolaan KSU Pusat Grosir Butung di Kota Makassar".

\section{Rumusan Masalah}

Berdasarkan latar belakang di atas, maka yang menjadi masalah pokok adalah sebagai berikut:

1. Apakah kualitas pelayanan yang terdiri atas: kehandalan, ketanggapan, emp ...., jaminan, dan tampilan fisik berpengaruh signifikan terhadap kepuasan pedagang pada Pengelolaan KSU Pusat Grosir Butung di Kota Makassar?

2. variabel manakah yang berpengaruh dominan terhadap kepuasan pedagang pada Pengelolaan KSU Pusat Grosir Butung di Kota Makassar?

\section{METODE PENELITIAN}

\section{Tempat dan Waktu Penelitian}

Penelitian ini dilaksanakan pada Pengelolaan KSU Pusat Grosir Butung di Kota Makassar, dengan pertimbangan penulis lebih mudah dalam pengumpulan data, baik yang bersifat data primer maupun data sekunder. Sedangkan waktu yang dibutuhkan untuk melakukan pengumpulan data yaitu selama lebih kurang 3 bulan yaitu Juni sampai Agustus 2013.

\section{Metode Pengumpulan Data}

Metode pengumpulan data yang digunakan adalah sebagai berikut:

1. Wawancara (interview), yaitu pengumpulan data melalui wawancara secara langsung dengan para informan penelitian.

2. Observasi (observation) yaitu melakukan pengumpulan data melalui pengamatan langsung mengenai kualitas pelayanan bagi pedagang untuk memperoleh data yang berkaitan dengan penelitian ini.

3. Kuesioner (questioner) yaitu melakukan pengumpulan data melalui daftar pertanyaan kepada responden.

4. Telaah dokumen yaitu pengumpulan data-data melalui buku-buku, laporan, jurnal atau tulisan ilmiah, serta dokumen yang berhubungan dengan penelitian ini.

\section{Jenis dan Sumber Data}

\section{Jenis Data}

Jenis data yang digunakan dalam penelitian ini adalah:

a. Data kualitatif adalah data yang berbentuk kalimat, kata atau gambar, seperti: profil organisasi, struktur organisasi, uraian tugas dan fungsi personil. 
b. Data kuantitatif adalah data yang berbentuk angka atau data kualitatif yang diangkakan (skoring).

\section{Jenis Data}

Sumber data yang digunakan dalam penelitian ini adalah:

a. Data primer

Data primer adalah data yang diperoleh dengan menggunakan daftar pertanyaan yang telah terstruktur dengan tujuan untuk mengumpulkan informasi dari responden pada lokasi penelitian.

b. Data sekunder

Data yang diperoleh dari berbagai sumber, antara lain: dokumentasi, buku-buku, laporan-laporan, karya ilmiah dan hasil penelitian seperti data karyawan, gambaran umum lokasi penelitian dan lain-lain.

\section{Populasi dan Sampel}

Dalam penelitian ini populasi terdiri dari seluruh pedagang yang terdaftar menjadi anggota KSU di Pusat Grosir Butung Kota Makassar sebanyak 644 orang.

Sampel adalah suatu himpunan atau bagian dari unit populasi. Untuk menentukan ukuran sampel dari suatu populasi dapat digunakan formulasi Slovin (1960) dalam Sugiyono (2008) sebagai berikut:

$$
\mathrm{n}=\frac{\mathrm{N}}{1+\mathrm{Ne}^{2}}
$$

Dimana: $\mathrm{n}=$ Ukuran sampel

$\mathrm{N}=$ Ukuran populasi

$\mathrm{e}=$ Persen kelonggaran ketidaktelitian (presisi) karena kesalahan sampel yang masih bisa ditolerir (bound of error) atau dalam penelitian ini dipakai 0,05

Berdasarkan formulasi di atas, maka jumlah sampel minimal yang harus diperoleh adalah:

$$
\begin{aligned}
\mathrm{n} & =\frac{644}{1+644(0,05)^{2}} \\
& =246,74 \text { atau ditetapkan } 247 \text { sampel. }
\end{aligned}
$$

Dengan demikian, jumlah sampel yang diambil sebanyak 247 orang pedagang yang terdaftar menjadi anggota KSU di Pusat Grosir Butung Makassar.

\section{HASIL PENELITIAN DAN PEMBAHASAN Deskripsi Karakteristik Responden}

Karakteristik responden dapat diketahui dari hasil penelitian yang dilakukan pada Pengelolaan KSU Pusat Grosir Butung di Kota Makassar yang berjumlah 267 orang responden yang meliputi: jenis kelamin, tingkat umur, dan tingkat pendidikan. Adapun karakteristik responden, dapat dijelaskan sebagai berikut: 


\section{Jenis Kelamin}

Jumlah responden yang digunakan dalam penelitian ini adalah 247 orang, dengan jenis kelamin terdiri atas: laki-laki dan perempuan. Adapun distribusi responden menurut jenis kelamin dapat dilihat pada Tabel 2.

Tabel 2. Distribusi Responden menurut Jenis Kelamin pada Pengelolaan KSU Pusat

Grosir Butung di Kota Makassar

\begin{tabular}{|c|c|c|c|}
\hline No. & Jenis Kelamin & Frekuensi (orang) & Persentase $(\%)$ \\
\hline 1. & Laki-laki & 136 & 55,10 \\
\hline 2. & Perempuan & 111 & 44,90 \\
\hline & Jumlah & 247 & 100,00 \\
\hline
\end{tabular}

Sumber: Data Primer, 2012

Berdasarkan data pada Tabel 2, dapat dijelaskan bahwa komposisi responden menurut jenis kelamin yang terbanyak adalah jenis kelamin laki-laki yakni 136 orang atau $55,10 \%$, sedangkan perempuan hanya 111 orang atau 44,90\%, artinya laki-laki lebih banyak dibanding perempuan. Hal ini disebabkan karena kemampuan memiliki keterbatasan fisik dibanding laki-laki yang memiliki keberanian, namunpun demikian baik laki-laki maupun perempuan diharapkan dapat bekerjasama dengan baik.

\section{Tingkat Umur}

Umur masing-masing responden berada pada interval 28 tahun sampai dengan 55 tahun. Tingkat umur tersebut diharapkan mampu memberikan tanggapan yang objektif tentang kepuasan pasien atas pelayanan yang diberikan petugas kesehatan di pada Pengelolaan KSU Pusat Grosir Butung di Kota Makassar. Adapun distribusi responden menurut tingkat umur dapat dilihat pada Tabel 3.

Tabel 3. Distribusi Responden menurut Tingkat Umur pada Pengelolaan KSU Pusat Grosir Butung di Kota Makassar

\begin{tabular}{|c|c|c|c|}
\hline No. & $\begin{array}{c}\text { Tingkat Umur } \\
\text { (tahun) }\end{array}$ & $\begin{array}{c}\text { Frekuensi } \\
\text { (orang) }\end{array}$ & $\begin{array}{c}\text { Persentase } \\
(\boldsymbol{\%})\end{array}$ \\
\hline 1. & $\leq 34$ & 53 & 21,46 \\
2. & $35-41$ & 114 & 46,15 \\
3. & $42-48$ & 42 & 17,01 \\
4. & $\geq 49$ & 38 & 15,38 \\
\hline \multicolumn{2}{|r|}{ Jumlah } & 247 & 100,00 \\
\hline
\end{tabular}

Sumber: Data Primer, 2013

Berdasarkan data pada Tabel 3 dapat dijelaskan bahwa responden yang memiliki proporsi tingkat umur terbanyak berada pada tingkat umur $35-41$ tahun yakni 114 orang responden atau 46,15\%, dan kemudian diikuti tingkat umur 34 tahun ke bawah sebanyak 53 orang atau 21,46\%, interval 42 - 48 tahun sebanyak 42 orang atau 17,01\%, dan tingkat umur 49 tahun ke atas sebanyak 38 orang atau 15,38\%. Tingkat umur tersebut tentu akan memberikan persepsi yang berbeda tentang kualitas pelayanan terhadap kepuasan pedagang pada Pengelolaan KSU Pusat Grosir Butung di Kota Makassar. 


\section{Tingkat Pendidikan}

Tingkat pendidkan adalah jenjang pendidikan yang telah ditamati oleh responden sesuai dengan latar belakang pendidikan dan disiplin ilmu yang ditekuninya. Adapun karakteristik responden menurut tingkat pendidikan pada Pengelolaan KSU Pusat Grosir Butung di Kota Makassar dapat dilihat pada Tabel 4 berikut ini.

Tabel 4. Karakteristik Responden Menurut Tingkat Pendidikan pada Pengelolaan KSU Pusat Grosir Butung di Kota Makassar.

\begin{tabular}{|l|c|c|}
\hline Tingkat Pendidikan & $\begin{array}{c}\text { Jumlah } \\
\text { (orang) }\end{array}$ & $\begin{array}{c}\text { Persentase } \\
(\%)\end{array}$ \\
\hline Sarjana & 35 & 14,20 \\
SD & 74 & 30,00 \\
SLTA & 73 & 29,50 \\
SLTP & 65 & 17,30 \\
\hline \multicolumn{1}{|c|}{ Jumlah } & 247 & 100,00 \\
\hline
\end{tabular}

Sumber: Data Primer, 2013

Tabel 4 menunjukkan karakteristik responden berdasarkan tingkat pendidikan diperoleh data yang variatif. Data yang terjaring menunjukkan tingkat SD merupakan responden terbanyak yakni sebanyak 74 orang (30\%)., kemudian disusul tingkat pendidikan SLTA sebanyak 73 orang (29,5\%), dan SLTP sebanyak 65 orang $(17,3 \%)$, sedangkan tingkat pendidikan yang paling sedikit yaitu Sarjana sebanyak 35 orang $(14,2 \%)$.

\section{Pengujian Instrumen Penelitian}

\section{Uji Validitas}

Uji validitas dilakukan dengan mengkorelasikan skor tiap item dengan skor total dari masing-masing atribut. Uji validitas digunakan untuk melihat ketepatan dan kecermatan dari sebuah instrumen penelitian dalam fungsi ukurnya mengukur item-item pernyataan yang dibuat. Instrumen yang valid mempunyai arti bahwa alat ukur yang digunakan dalam bentuk pernyataan untuk memperoleh data (mengukur) juga dinyatakan valid. Item pernyataan yang memiliki korelasi positif tinggi dapat dianggap memiliki validitas yang tinggi pula.

Menurut Sugiyono (2007:233), corrected item total corelation merupakan korelasi antar skor total item, sehingga interpretasinya dengan mengkonsultasikan nilai kritis r-tabel, jika $\mathrm{r}$ hitung $>$ nilai kritis r-tabel product moment maka instrument dinyatakan valid. Adapun hasil uji validitas dari setiap item pernyataan variabel dalam penelitian ini, dapat dilihat pada Tabel 11. 
Tabel 11. Hasil Uji Validitas Instrumen Penelitian

\begin{tabular}{|c|c|c|c|c|}
\hline Variabel & Item & $\begin{array}{c}\text { Corrected Item } \\
\text { Total } \\
\text { Correlation }\end{array}$ & $\begin{array}{c}\text { r-Product } \\
\text { Moment } \\
\text { r-tabel }\end{array}$ & Keterangan \\
\hline \multirow{3}{*}{$\begin{array}{l}\text { Kepuasan Pedagang } \\
\text { (Y) }\end{array}$} & 1 & 0,859 & 0,138 & Valid \\
\hline & 2 & 0,863 & 0,138 & Valid \\
\hline & 3 & 0,655 & 0,138 & Valid \\
\hline \multirow[t]{3}{*}{ Kehandalan $\left(\mathrm{X}_{1}\right)$} & 1 & 0,759 & 0,138 & Valid \\
\hline & 2 & 0,775 & 0,138 & Valid \\
\hline & 3 & 0,686 & 0,138 & Valid \\
\hline \multirow[t]{3}{*}{ Ketanggapan $\left(\mathrm{X}_{2}\right)$} & 1 & 0,866 & 0,138 & Valid \\
\hline & 2 & 0,775 & 0,138 & Valid \\
\hline & 3 & 0,875 & 0,138 & Valid \\
\hline \multirow[t]{3}{*}{$\operatorname{Empati}\left(\mathrm{X}_{3}\right)$} & 1 & 0,828 & 0,138 & Valid \\
\hline & 2 & 0,836 & 0,138 & Valid \\
\hline & 3 & 0,834 & 0,138 & Valid \\
\hline \multirow[t]{3}{*}{ Jaminan $\left(\mathrm{X}_{4}\right)$} & 1 & 0,869 & 0,138 & Valid \\
\hline & 2 & 0,835 & 0,138 & Valid \\
\hline & 3 & 0,778 & 0,138 & Valid \\
\hline \multirow[t]{3}{*}{ Tampilan fisik $\left(\mathrm{X}_{5}\right)$} & 1 & 0,724 & 0,138 & Valid \\
\hline & 2 & 0,798 & 0,138 & Valid \\
\hline & 3 & 0,784 & 0,138 & Valid \\
\hline
\end{tabular}

Sumber: Hasil Penelitian, 2013

Hasil uji validitas instrumen kepuasan pedagang diperoleh nilai Corrected Item Total Correlation ( $\mathrm{r}$ hitung) antara 0,655 - 0,863 atau $\mathrm{r}$ hitung $>\mathrm{r}$ tabel 0,138 yang berarti setiap butir pernyataan dari variabel kepuasan pedagang yang digunakan dalam penelitian ini adalah valid (sahih).

Hasil uji validitas instrumen kehandalan diperoleh nilai Corrected Item Total Correlation ( $\mathrm{r}$ hitung) antara 0,686 - 0,77 atau $\mathrm{r}$ hitung $>\mathrm{r}$ tabel 0,138 yang berarti setiap butir pernyataan dari variabel kehandalan yang digunakan dalam penelitian ini adalah valid (sahih). 
Hasil uji validitas instrumen ketanggapan diperoleh nilai Corrected Item Total Correlation ( $\mathrm{r}$ hitung) antara 0,775 - 0,875 atau $\mathrm{r}$ hitung $>\mathrm{r}$ tabel 0,138 yang berarti setiap butir pernyataan dari variabel responsiveness yang digunakan dalam penelitian ini adalah valid (sahih).

Hasil uji validitas instrumen empati diperoleh nilai Corrected Item Total Correlation ( $\mathrm{r}$ hitung) antara 0,828 - 0,836 atau $\mathrm{r}$ hitung $>\mathrm{r}$ tabel 0,138 yang berarti setiap butir pernyataan dari variabel empati yang digunakan dalam penelitian ini adalah valid (sahih).

Hasil uji validitas instrumen jaminan diperoleh nilai Corrected Item Total Correlation ( $\mathrm{r}$ hitung) antara 0,778 - 0,869 atau $\mathrm{r}$ hitung $>\mathrm{r}$ tabel 0,138, berarti setiap butir pernyataan dari variabel jaminan yang digunakan dalam penelitian ini adalah valid (sahih).

Hasil uji validitas instrumen tampilan fisik diperoleh nilai Corrected Item Total Correlation (r hitung) antara 0,724 - 0,798 atau $\mathrm{r}$ hitung $>\mathrm{r}$ tabel 0,138, yang berarti setiap butir pernyataan dari variabel kepuasan pedagang yang digunakan dalam penelitian ini adalah valid (sahih).

\section{Hasil Uji Reliabilitas}

Uji reliabilitas digunakan untuk melihat konsistensi jawaban. Pengujian reliabilitas (tingkat kehandalan) dari suatu variabel dapat dilakukan dengan melihat nilai Cronbach Alpha, dimana item pernyataan pada kuesioner memiliki nilai Cronbach Alpha > nilai kritis r-tabel Product Moment pada tingkat kepercayaan $95 \%$. Dengan demikian, dapat dikatakan bahwa item pernyataan dari cerminan setiap variabel dalam penelitian ini keberadaannya pada instrumen penelitian dinyatakan reliabel (handal).

Adapun uji reliabilitas dari setiap variabel penelitian dapat dilihat pada Tabel 12.

Tabel 12. Hasil Uji Reliabilitas Instrumen Penelitian

\begin{tabular}{|l|c|c|c|c|}
\hline \multicolumn{1}{|c|}{ Variabel } & Item & $\begin{array}{c}\text { Cronbach's } \\
\text { Alpha if Item } \\
\text { Deleted }\end{array}$ & $\begin{array}{c}\text { r-Product } \\
\text { Moment } \\
\text { r-tabel }\end{array}$ & Keterangan \\
\hline \multirow{2}{*}{$\begin{array}{l}\text { Kepuasan Pedagang } \\
(Y)\end{array}$} & 1 & 0,968 & 0,138 & Reliabel \\
\cline { 2 - 5 } & 2 & 0,968 & 0,138 & Reliabel \\
\cline { 2 - 5 } & 3 & 0,970 & 0,138 & Reliabel \\
\hline Kehandalan $\left(\mathrm{X}_{1}\right)$ & 1 & 0,969 & 0,138 & Reliabel \\
\cline { 2 - 5 } & 2 & 0,969 & 0,138 & Reliabel \\
\cline { 2 - 5 } & 3 & 0,970 & 0,138 & Reliabel \\
\hline Ketanggapan $\left(\mathrm{X}_{2}\right)$ & 1 & 0,968 & 0,138 & Reliabel \\
\cline { 2 - 5 } & 2 & 0,969 & 0,138 & Reliabel \\
\cline { 2 - 5 } & 3 & 0,968 & 0,138 & Reliabel \\
\hline Empati $\left(\mathrm{X}_{3}\right)$ & 1 & 0,968 & 0,138 & Reliabel \\
\cline { 2 - 5 } & 2 & 0,968 & 0,138 & Reliabel \\
\cline { 2 - 5 } & & &
\end{tabular}




\begin{tabular}{|l|c|c|c|c|}
\cline { 2 - 5 } \multicolumn{1}{c|}{} & 3 & 0,968 & 0,138 & Reliabel \\
\hline Jaminan $\left(\mathrm{X}_{4}\right)$ & 1 & 0,968 & 0,138 & Reliabel \\
\cline { 2 - 5 } & 2 & 0,968 & 0,138 & Reliabel \\
\cline { 2 - 5 } & 3 & 0,969 & 0,138 & Reliabel \\
\hline Tampilan fisik $\left(\mathrm{X}_{5}\right)$ & 1 & 0,969 & 0,138 & Reliabel \\
\cline { 2 - 5 } & 2 & 0,969 & 0,138 & Reliabel \\
\cline { 2 - 5 } & 3 & 0,969 & 0,138 & Reliabel \\
\hline
\end{tabular}

Sumber: Hasil Penelitian, 2013

Berdasarkan data pada Tabel 12 dapat dijelaskan bahwa nilai Cronbach Alpha dari keseluruhan item pernyataan dalam instrumen variabel penelitian diperoleh sebesar 0,970. Nilai ini memberikan makna bahwa tingkat konsistensi (keandalan) dari instrumen penelitian yang digunakan adalah sebesar 97\%. Artinya apabila kuesioner dalam penelitian ini akan digunakan secara berulang-ulang pada populasi akan memberikan nilai objektifitas, stabilitas, akurasi dan konsistensi tinggi dalam fungsi ukurnya setelah diterapkan.

Hasil uji reliabilitas instrumen dari variabel kehandalan nilai Cronbach Alpha (r hitung) antara 0,969 - 0,970 atau $\mathrm{r}$ hitung > $\mathrm{r}$ tabel 0,138, yang berarti setiap butir pernyataan dari variabel kehandalan yang digunakan dalam penelitian ini adalah reliabel (handal). Dengan demikian, dapat dikatakan bahwa instrumen penelitian yang digunakan dalam fungsi ukurnya tidak menimbulkan arti ganda sehingga terjamin konsistensinya dalam mengukur pengaruh variabel kehandalan terhadap kepuasan pedagang pada Pengelolaan KSU Pusat Grosir Butung di Kota Makassar.

Hasil uji reliabilitas instrumen dari variabel ketanggapan nilai Cronbach Alpha $(\mathrm{r}$ hitung) antara 0,968 - 0,969 atau $\mathrm{r}$ hitung > $\mathrm{r}$ tabel 0,138, yang berarti setiap butir pernyataan dari variabel ketanggapan yang digunakan dalam penelitian ini adalah reliabel (handal). Dengan demikian, dapat dikatakan bahwa instrumen penelitian yang digunakan dalam fungsi ukurnya tidak menimbulkan arti ganda sehingga terjamin konsistensinya dalam mengukur pengaruh variabel ketanggapan terhadap kepuasan pedagang pada Pengelolaan KSU Pusat Grosir Butung di Kota Makassar.

Hasil uji reliabilitas instrumen dari variabel empati nilai Cronbach Alpha (r hitung) 0,968 atau $\mathrm{r}$ hitung $>\mathrm{r}$ tabel 0,138 , yang berarti setiap butir pernyataan dari variabel empati yang digunakan dalam penelitian ini adalah reliabel (handal). Dengan demikian, dapat dikatakan bahwa instrumen penelitian yang digunakan dalam fungsi ukurnya tidak menimbulkan arti ganda sehingga terjamin konsistensinya dalam mengukur pengaruh variabel empati terhadap kepuasan pedagang pada Pengelolaan KSU Pusat Grosir Butung di Kota Makassar.

Hasil uji reliabilitas instrumen dari variabel jaminan nilai Cronbach Alpha (r hitung) antara 0,968 - 0,969 atau $\mathrm{r}$ hitung > $\mathrm{r}$ tabel 0,138, yang berarti setiap butir pernyataan dari variabel jaminan yang digunakan dalam penelitian ini adalah reliabel (handal). Dengan demikian, dapat dikatakan bahwa instrumen penelitian yang digunakan dalam fungsi ukurnya tidak menimbulkan arti ganda sehingga terjamin konsistensinya dalam mengukur pengaruh variabel assurance terhadap kepuasan pedagang pada Pengelolaan KSU Pusat Grosir Butung di Kota Makassar. 
Hasil uji reliabilitas instrumen dari variabel tampilan fisik nilai Cronbach Alpha ( $\mathrm{r}$ hitung) antara 0,968 - 0,970 atau $\mathrm{r}$ hitung $>\mathrm{r}$ tabel 0,138, yang berarti setiap butir pernyataan dari variabel tampilan fisik yang digunakan dalam penelitian ini adalah reliabel (handal). Dengan demikian, dapat dikatakan bahwa instrumen penelitian yang digunakan dalam fungsi ukurnya tidak menimbulkan arti ganda sehingga terjamin konsistensinya dalam mengukur pengaruh variabel tampilan fisik terhadap kepuasan pedagang pada Pengelolaan KSU Pusat Grosir Butung di Kota Makassar.

Hasil uji reliabilitas instrumen dari variabel kepuasan pedagang nilai Cronbach Alpha (r hitung) antara 0,968 - 0,970 atau $\mathrm{r}$ hitung $>\mathrm{r}$ tabel 0,138, yang berarti setiap butir pernyataan dari variabel kepuasan pedagang yang digunakan dalam penelitian ini adalah reliabel (handal). Dengan demikian, dapat dikatakan bahwa instrumen penelitian yang digunakan dalam fungsi ukurnya tidak menimbulkan arti ganda sehingga terjamin konsistensinya dalam mengukur kepuasan pedagang pada Pengelolaan KSU Pusat Grosir Butung di Kota Makassar.

\section{Pengujian Asumsi Klasik}

\section{Pengujian Hipotesis secara Serempak}

Pengujian secara serempak bertujuan untuk melihat pengaruh kehandalan, ketanggapan, empati, jaminan, dan tampilan fisik terhadap kepuasan pedagang pada Pengelolaan KSU Pusat Grosir Butung di Kota Makassar dengan melihat nilai Fhitungnya. Adapun hasil pengujian secara serempak, dapat dilihat pada Tabel 14.

Tabel 14. Pengujian Secara Serempak (Uji F)

\begin{tabular}{|ll|r|r|r|r|r|}
\hline \multicolumn{7}{|c|}{ ANOVA $^{\mathbf{b}}$} \\
\multicolumn{2}{|l|}{ Model } & $\begin{array}{c}\text { Sum of } \\
\text { Squares }\end{array}$ & Df & Mean Square & F & Sig. \\
\hline 1 & Regression & 51.686 & 5 & 10.337 & 219.935 & $.000^{\text {a }}$ \\
& Residual & 11.327 & 241 & .047 & & \\
& Total & 63.013 & 246 & & & \\
\hline
\end{tabular}

a. Predictors: (Constant), X5, X1, X4, X3,

$\mathrm{X} 2$

b. Dependent Variable: Y

Sumber: Hasil Analisis Data, 2013 (Lampiran 7)

Data pada Tabel 14 menunjukkan bahwa nilai F-hitung yang diperoleh adalah 332,079 , sedangkan F-tabel $(\mathrm{df} 1=5 ; \mathrm{df} 2=241)$ pada tingkat kesalahan $(\alpha=0,05)$ diperoleh 2,26 dengan tingkat signifikansi 0,000. Dengan demikian, nilai F-hitung > Ftabel atau 219,935 > 2,26 yang berarti berpengaruh signifikan pada tingkat alpha yang sangat kecil (0\%). Dengan hasil ini, maka dapat disimpulkan bahwa secara serempak kualitas pelayanan yang terdiri atas: variabel kehandalan, ketanggapan, empati, jaminan, dan tampilan fisik berpengaruh positif dan signifikan terhadap kepuasan pedagang pada Pengelolaan KSU Pusat Grosir Butung di Kota Makassar. 
Selanjutnya pengujian koefisien determinasi $\left(\mathrm{R}^{2}\right)$ digunakan untuk mengetahui seberapa besar pengaruh dari seluruh variabel bebas terhadap variabel terikatnya. Perolehan nilai $\mathrm{R}^{2}$ dapat dilihat pada Tabel 15.

Tabel 15. Hasil Pengujian Koefisien Determinasi ( $\left.\mathrm{R}^{\mathbf{2}}\right)$

Model Summary ${ }^{\mathrm{b}}$

\begin{tabular}{|l|r|r|r|r|}
\hline Model & $\mathrm{R}$ & R Square & \multicolumn{1}{|c|}{$\begin{array}{c}\text { Adjusted R } \\
\text { Square }\end{array}$} & $\begin{array}{c}\text { Std. Error of the } \\
\text { Estimate }\end{array}$ \\
\hline 1 & $.906^{\mathrm{a}}$ & .820 & .817 & .21680 \\
\hline
\end{tabular}

a. Predictors: (Constant), X5, X1, X3, X4, X2

b. Dependent Variable: Y

Sumber: Hasil Analisis Data, 2013 (Lampiran 7)

Berdasarkan hasil pengujian determinasi tersebut di atas, dapat dijelaskan bahwa besarnya koefisien determinasi $\left(\mathrm{R}^{2}\right)$ adalah 0,820. Angka koefisien determinasi ini menyatakan bahwa besarnya pengaruh variabel kehandalan, ketanggapan, empati, jaminan, dan tampilan fisik terhadap kepuasan pedagang pada Pengelolaan KSU Pusat Grosir Butung di Kota Makassar adalah sebesar 82\%, sedangkan sisanya sebesar $18 \%$ dipengaruhi oleh variabel lain yang tidak diteliti dalam penelitian ini.

\section{Pengujian Hipotesis secara Parsial}

Pengujian hipotesis secara parsial digunakan untuk melihat pengaruh secara individu variabel kehandalan, ketanggapan, empati, jaminan, dan tampilan fisik terhadap kepuasan pedagang pada Pengelolaan KSU Pusat Grosir Butung di Kota Makassar. Hasil pengujiannya dapat dilihat melalui nilai t-hitungnya. Adapun hasil pengujian secara parsial (t-hitung) dapat dilihat pada Tabel 16.

Tabel 16. Pengujian Secara Parsial (Uji-t)

\begin{tabular}{|c|c|c|c|c|c|c|}
\hline \multirow{2}{*}{\multicolumn{2}{|c|}{ Model }} & \multicolumn{2}{|c|}{$\begin{array}{c}\text { Unstandardized } \\
\text { Coefficients }\end{array}$} & \multirow{2}{*}{$\begin{array}{c}\text { Standardized } \\
\text { Coefficients } \\
\text { Beta }\end{array}$} & \multirow[b]{2}{*}{$\mathrm{t}$} & \multirow[b]{2}{*}{ Sig. } \\
\hline & & B & Std. Error & & & \\
\hline 1 & (Constant) & .080 & .178 & & .448 & .655 \\
\hline & $\mathrm{X} 1$ & .262 & .064 & .253 & 4.123 & .000 \\
\hline & $\mathrm{X} 2$ & .121 & .098 & .119 & 1.234 & .126 \\
\hline & X3 & .241 & .065 & .230 & 3.713 & .000 \\
\hline & $\mathrm{X} 4$ & .227 & .085 & .211 & 2.662 & .008 \\
\hline & $\mathrm{X} 5$ & .138 & .083 & .140 & 1.663 & .079 \\
\hline
\end{tabular}

a. Dependent Variable: Y

Sumber: Data Diolah, 2013 (Lampiran 7)

Berdasarkan pengujian secara parsial seperti pada Tabel 16 menunjukkan bahwa kualitas pelayanan yang terdiri atas: kehandalan, empati, dan jaminan secara individu berpengaruh signifikan dan positif terhadap kepuasan pedagang pada Pengelolaan KSU Pusat Grosir Butung di Kota Makassar. Sedangkan variabel ketanggapan dan tampilan 
fisik berpengaruh tidak signifikan terhadap kepuasan pedagang. Adanya pengaruh sgnifikan tersebut dapat dilihat dari nilai t-hitung yang diperoleh dan juga dapat diketahui melalui tingkat signifikansinya dimana pada kolom sig./probabilitas pada tabel di atas diperoleh nilai signifikansi dari ketiga variabel bebas yang signifikan tersebut memiliki nilai signifikansi lebih kecil dari 0,05 yakni kehandalan dengan nilai sig. 0,000 $<0,05$, empati dengan nilai sig. 0,000 <0,05, dan jaminan dengan nilai sig. 0,008< 0,05 . Sedangkan variabel yang berpengaruh tidak signifikan adalah ketanggapan dengan nilai sig. $0,126<0,05$ dan tampilan dengan nilai sig. $0,079<0,05$. Dari tiga variabel bebas yang berpengaruh signifikan tersebut, variabel yang memperlihatkan pengaruh dominan adalah variabel kehandalan karena nilai t-hitung yang diperoleh lebih besar dari variabel lain.

Selanjutnya pada Tabel 15, dapat pula diketahui hasil persamaan regresi linier berganda dari model penelitian ini adalah sebagai berikut:

$\mathrm{Y}=0,080+0,262 \mathrm{X} 1+0,121 \mathrm{X} 2+0,241 \mathrm{X} 3+0,227 \mathrm{X} 4+0,138 \mathrm{X} 5$

Berdasarkan persamaan regresi linier berganda tersebut di atas, maka dapat diinterprestasi sebagai berikut:

a. Konstanta (b0) =0,080, yang menunjukkan bahwa jika tidak dilakukan upaya peningkatan kepuasan pedagang melalui kualitas pelayanan yang terkait dengan kehandalan, ketanggapan, empati, jaminan, dan tampilan fisik, maka kepuasan pedagang akan konstan atau tetap yang jika diangkakan adalah 0,080.

b. b1 $=0,262$, yang menunjukkan bahwa variabel kehandalan berpengaruh positif dan signifikan terhadap kepuasan pedagang pada Pengelolaan KSU Pusat Grosir Butung di Kota Makassar. Hal ini berarti semakin baik kehandalan, maka kepuasan pedagang akan cenderung meningkat. Besarnya pengaruh variabel kehandalan terhadap kepuasan pedagang dapat diketahui melalui angka beta atau standardized coefficient yaitu 0,253 atau 25,3 persen.

c. b2 $=0,121$, yang menunjukkan bahwa variabel ketanggapan berpengaruh tidak signifikan terhadap kepuasan pedagang pada Pengelolaan KSU Pusat Grosir Butung di Kota Makassar. Hal ini berarti variabel ketanggapan belum dapat meningkatkan kepuasan pedagang secara signifikan, sehingga perlu ditingkatkan. Besarnya pengaruh variabel ketanggapan terhadap kepuasan pedagang dapat diketahui melalui angka beta atau standardized coefficient yaitu 0,119 atau 11,9 persen.

d. b3 $=0,241$, yang menunjukkan bahwa variabel empati berpengaruh positif dan signifikan terhadap kepuasan pedagang pada Pengelolaan KSU Pusat Grosir Butung di Kota Makassar. Hal ini berarti semakin baik empati, maka kepuasan pedagang akan cenderung meningkat. Besarnya pengaruh variabel empati terhadap kepuasan pedagang dapat diketahui melalui angka beta atau standardized coefficient yaitu 0,230 atau 23 persen.

e. b4 $=0,227$, yang menunjukkan bahwa jaminan berpengaruh positif dan signifikan terhadap kepuasan pedagang pada Pengelolaan KSU Pusat Grosir Butung di Kota Makassar. Hal ini berarti semakin baik jaminan, maka kepuasan pedagang akan cenderung meningkat. Besarnya pengaruh variabel jaminan terhadap kepuasan pedagang dapat diketahui melalui angka beta atau standardized coefficient yaitu 0,211 atau 21,1 persen.

f. b5 $=0,138$, yang menunjukkan bahwa variabel tampilan fisik berpengaruh tidak signifikan terhadap kepuasan pedagang pada Pengelolaan KSU Pusat Grosir Butung 
di Kota Makassar. Hal ini berarti tampilan fisik belum mempu meningkatkan kepuasan pedagang secara signifikan, sehingga perlu ditingkatkan. Besarnya pengaruh variabel tampilan fisik terhadap kepuasan pedagang dapat diketahui melalui angka beta atau standardized coefficient yaitu 0,140 atau 14 persen.

Berdasarkan uraian di atas dapat diketahui bahwa dari keempat variabel yang signifikan, ternyata variabel kehandalan yang mempunyai pengaruh dominan dalam meningkatkan kepuasan pedagang pada Pengelolaan KSU Pusat Grosir Butung di Kota Makassar, karena diperoleh beta atau standardized coefficient yang lebih besar dari variabel lainnya.

\section{PEMBAHASAN}

Selanjutnya pembahasan mengenai pengaruh variabel kehandalan, ketanggapan, empati, jaminan, dan tampilan fisik terhadap kepuasan pedagang pada Pengelolaan KSU Pusat Grosir Butung di Kota Makassar, akan diuraikan berikut ini.

\section{Pengaruh kehandalan terhadap kepuasan pedagang}

Berdasarkan hasil uji-t menunjukkan bahwa variabel kehandalan berpengaruh positif dan signifikan terhadap kepuasan pedagang pada Pengelolaan KSU Pusat Grosir Butung di Kota Makassar. Hal ini mengindikasikan ada hubungan yang searah antara kehandalan dengan kepuasan pedagang, dalam arti jika terjadi peningkatan kehandalan maka kepuasan pedagang juga akan meningkat.

Variabel kehandalan memberikan pengaruh signifikan terhadap kepuasan pedagang dan menempati urutan pertama dari variabel bebas yang telah diuji. Karena itu, variabel kehandalan merupakan salah satu faktor penting dalam meningkatkan kepuasan pedagang, sehingga perlu dipertahankan, namun tetap memaksimalkan indikator yang memberikan proporsi terendah agar dapat meningkatkan kepuasan pedagang pada Pengelolaan KSU Pusat Grosir Butung di Kota Makassar.

Adanya pengaruh signifikan variabel kehandalan terhadap kepuasan pedagang sangat ditentukan oleh indikator pembentuknya, yaitu: (a) kecepatan pelayanan kredit usaha; (b) ketepatan pelayanan kredit usaha; dan (c) Kelancaran pelayanan kredit usaha. Dari ketiga butir indikator tersebut, maka indikator yang dominan dalam membentuk variabel kehandalan pelayanan pada Pengelolaan KSU Pusat Grosir Butung di Kota Makassar adalah indikator kecepatan pelayanan kredit usaha mempunyai nilai rata-rata 4,60, kemudian diikuti indikator ketepatan pelayanan kredit usaha mempunyai nilai rata-rata 4,59. Sedangkan indikator kelancaran pelayanan kredit usaha mempunyai nilai rata-rata 4,47 memberikan proporsi terkecil dalam membentuk variabel kehandalan, sehingga perlu diberdayakan secara maksimal agar kepuasan pedagang pada Pengelolaan KSU Pusat Grosir Butung di Kota Makassar dapat ditingkatkan di masa akan datang.

\section{Pengaruh ketanggapan terhadap kepuasan pedagang}

Hasil pengujian secara parsial menunjukkan bahwa variabel ketanggapan berpengaruh tidak signifikan terhadap kepuasan pedagang pada Pengelolaan KSU Pusat Grosir Butung di Kota Makassar. Hal ini mengindikasikan variabel ketanggapan belum mampu meningkatkan kepuasan pedagang, dalam arti pelayanan yang terkait dengan ketanggapan belum memberikan peningkatan kepuasan pedagang secara signifikan. Oleh karena itu, pelayanan yang terkait dengan ketanggapan perlu mendapat perhatian 
khusus untuk lebih ditingkatkan dengan memaksimalkan indikator yang membentuknya agar dapat meningkatkan kepuasan pedagang pada Pengelolaan KSU Pusat Grosir Butung di Kota Makassar.

Pengaruh non signifikan variabel ketanggapan terhadap kepuasan pedagang sangat ditentukan oleh peran indikator yang membentuknya, yaitu: (a) Kecepatan mengatasi keluhan pedagang; (a) Menjelaskan prosedur yang tidak dipahami pedagang terkait dengan kredit usaha; dan (c) Penyampaian informasi dengan jelas tentang kredit usaha. Dari ketiga butir indikator tersebut, maka indikator yang dominan dalam membentuk ketanggapan adalah indikator kecepatan mengatasi keluhan pedagang mempunyai nilai rata-rata 4,64, kemudian diikuti indikator menjelaskan prosedur yang tidak dipahami pedagang mempunyai nilai rata-rata 4,58. Sedangkan indikator penyampaian informasi dengan jelas tentang kredit usaha mempunyai nilai rata-rata 4,42 memberikan proporsi terkecil dalam membentuk variabel ketanggapan, sehingga perlu diberdayakan secara maksimal semua indikator tersebut agar kepuasan pedagang dapat meningkat secara signifikan.

Berdasarkan analisa tersebut, maka dapat disimpulkan bahwa variabel ketanggapan berpengaruh tidak signifikan terhadap kepuasan pedagang pada Pengelolaan KSU Pusat Grosir Butung di Kota Makassar. Oleh karena itu, ketanggapan perlu mendapat perhatian khusus untuk lebih ditingkatkan terutama pada indikator yang membentuknya agar kepuasan pedagang pada Pengelolaan KSU Pusat Grosir Butung di Kota Makassar dapat ditingkatkan di masa akan datang.

\section{Pengaruh empati terhadap kepuasan pedagang}

Hasil pengujian secara parsial menunjukkan bahwa variabel empati berpengaruh positif dan signifikan terhadap kepuasan pedagang pada Pengelolaan KSU Pusat Grosir Butung di Kota Makassar. Hal ini mengindikasikan ada hubungan yang searah antara empati dengan kepuasan pedagang, dalam arti jika terjadi peningkatan empati, maka kepuasan pedagang juga akan meningkat.

Variabel empati memberikan pengaruh signifikan terhadap kepuasan pedagang dan menempati urutan kedua dari variabel bebas yang telah diuji. Karena itu, variabel empati juga merupakan salah satu faktor penting dalam meningkatkan kepuasan pedagang, sehingga perlu ditingkatkan dengan memaksimalkan indikator-indikator yang membentuknya agar dapat meningkatkan kepuasan pedagang pada Pengelolaan KSU Pusat Grosir Butung di Kota Makassar.

Adanya pengaruh signifikan variabel empati terhadap kepuasan pedagang sangat ditentukan oleh peran indikator yang membentuknya, yaitu: (a) Ramah kepada pedagang; (b) Sopan dalam bertutur kata dengan pedagang; dan (c) Memberikan pelayanan yang adil kepada pedagang terkait dengan kredit usaha. Dari ketiga butir indikator tersebut, maka indikator yang dominan dalam membentuk variabel empati pada Pengelolaan KSU Pusat Grosir Butung di Kota Makassar adalah indikator memberikan pelayanan yang adil kepada pedagang mempunyai nilai rata-rata 4,78, kemudian diikuti indikator ramah kepada pedagang mempunyai nilai rata-rata 4,68. Sedangkan indikator sopan dalam bertutur kata dengan pedagang mempunyai nilai ratarata 4,57 memberikan proporsi terkecil dalam membentuk variabel empati, sehingga perlu diberdayakan secara maksimal agar kepuasan pedagang dapat ditingkatkan. 
Berdasarkan analisa tersebut, maka dapat disimpulkan bahwa variabel empati berpengaruh positif dan signifikan terhadap kepuasan pedagang pada Pengelolaan KSU Pusat Grosir Butung di Kota Makassar. Oleh karena itu, empati perlu ditingkatkan terutama pada indikator yang membentuknya agar kepuasan pedagang pada Pengelolaan KSU Pusat Grosir Butung di Kota Makassar dapat ditingkatkan.

\section{Pengaruh jaminan terhadap kepuasan pedagang}

Hasil pengujian secara parsial menunjukkan bahwa variabel jaminan berpengaruh signifikan terhadap kepuasan pedagang pada Pengelolaan KSU Pusat Grosir Butung di Kota Makassar. Hal ini mengindikasikan ada hubungan yang searah antara jaminan dengan kepuasan pedagang, dalam arti jika terjadi peningkatan jaminan maka kepuasan pedagang juga akan meningkat.

Variabel jaminan memberikan pengaruh signifikan terhadap kepuasan pedagang dan menempati urutan ketiga dari variabel bebas yang telah diuji. Karena itu, variabel jaminan juga merupakan salah satu faktor penting dalam meningkatkan kepuasan pedagang, sehingga perlu ditingkatkan dengan memaksimalkan indikator yang memberikan proporsi terendah agar dapat meningkatkan kepuasan pedagang pada Pengelolaan KSU Pusat Grosir Butung di Kota Makassar.

Adanya pengaruh signifikan variabel jaminan terhadap kepuasan pedagang sangat ditentukan oleh indikator yang membentuknya, yaitu: (a) adanya jaminan keamanan; (b) kemampuan petugas; dan (c) memahami kebutuhan para pedagang. Dari ketiga butir indikator tersebut, maka indikator yang dominan dalam membentuk variabel jaminan adalah indikator adanya jaminan keamanan mempunyai nilai ratarata 4,79, kemudian diikuti indikator kemampuan petugas mempunyai nilai rata-rata 4,64. Sedangkan indikator memahami kebutuhan para pedagang mempunyai nilai ratarata 4,58 memberikan proporsi terkecil dalam membentuk variabel jaminan, sehingga perlu diberdayakan secara maksimal agar kepuasan pedagang dapat ditingkatkan di masa akan datang

Berdasarkan analisa tersebut, maka dapat disimpulkan bahwa variabel jaminan berpengaruh positif dan signifikan terhadap kepuasan pedagang pada Pengelolaan KSU Pusat Grosir Butung di Kota Makassar. Oleh karena itu, jaminan masih perlu ditingkatkan terutama pada indikator yang membentuknya agar kepuasan pedagang pada Pengelolaan KSU Pusat Grosir Butung di Kota Makassar dapat ditingkatkan di masa akan datang.

\section{Pengaruh tampilan fisik terhadap kepuasan pedagang}

Hasil pengujian secara parsial menunjukkan bahwa variabel tampilan fisik berpengaruh tidak signifikan terhadap kepuasan pedagang pada Pengelolaan KSU Pusat Grosir Butung di Kota Makassar. Hal ini mengindikasikan variabel tampilan fisik belum mampu meningkatkan kepuasan pedagang, dalam arti pelayanan yang terkait dengan tampilan fisik belum memberikan peningkatan kepuasan pedagang secara signifikan. Oleh karena itu, pelayanan yang terkait dengan tampilan fisik perlu mendapat perhatian khusus untuk lebih ditingkatkan dengan memaksimalkan indikator yang membentuknya agar dapat meningkatkan kepuasan pedagang pada Pengelolaan KSU Pusat Grosir Butung di Kota Makassar.

Pengaruh non signifikan variabel tampilan fisik terhadap kepuasan pedagang sangat ditentukan oleh peran indikator yang membentuknya, yaitu: (a) Kecepatan 
mengatasi keluhan pedagang;

(a) Menjelaskan prosedur yang tidak dipahami pedagang terkait dengan kredit usaha; dan (c) Penyampaian informasi dengan jelas tentang kredit usaha. Dari ketiga butir indikator tersebut, maka indikator yang dominan dalam membentuk tampilan fisik adalah indikator kecepatan mengatasi keluhan pedagang mempunyai nilai rata-rata 4,64, kemudian diikuti indikator menjelaskan prosedur yang tidak dipahami pedagang mempunyai nilai rata-rata 4,58. Sedangkan indikator penyampaian informasi dengan jelas tentang kredit usaha mempunyai nilai rata-rata 4,42 memberikan proporsi terkecil dalam membentuk variabel ketanggapan, sehingga perlu diberdayakan secara maksimal semua indikator tersebut agar kepuasan pedagang dapat meningkat secara signifikan.

Berdasarkan analisa tersebut, maka dapat disimpulkan bahwa variabel tampilan fisik berpengaruh tidak signifikan terhadap kepuasan pedagang pada Pengelolaan KSU Pusat Grosir Butung di Kota Makassar. Oleh karena itu, tampilan fisik perlu mendapat perhatian khusus untuk lebih ditingkatkan terutama pada indikator yang membentuknya agar kepuasan pedagang pada Pengelolaan KSU Pusat Grosir Butung di Kota Makassar dapat ditingkatkan di masa akan datang.

\section{KESIMPULAN \\ Simpulan}

Berdasarkan uraian dan hasil analisis yang ditunjukkan pada bab sebelumnya, dapat disimpulkan hal-hal sebagai berikut:

1. Hasil pengujian secara simultan atau bersama-sama menunjukkan variabel kehandalan, ketanggapan, empati, jaminan, dan tampilan fisik, berpengaruh positif dan signifikan terhadap kepuasan pedagang pada Pengelolaan KSU Pusat Grosir Butung di Kota Makassar. Selanjutnya hasil pengujian secara parsial menunjukkan bahwa variabel kehandalan, empati, dan jaminan berpengaruh signifikan terhadap kepuasan pedagang, sedangkan variabel ketanggapan, dan tampilan fisik berpengaruh tidak signifikan terhadap kepuasan pedagang.

2. Dari ketiga kualitas pelayanan yang berpengaruh signifikan tersebut, ternyata variabel kehandalan yang mampu meningkatkan kepuasan pedagang pada Pengelolaan KSU Pusat Grosir Butung di Kota Makassar dibandingkan variabel lainnya.

\section{Saran} berikut:

Berdasarkan kesimpulan di atas, maka penulis memberikan beberapa saran sebagai

1. Dalam penyusunan kebijakan pada Pengelolaan KSU Pusat Grosir Butung di Kota Makassar, maka perlu mempertimbangkan kualitas pelayanan yang meliputi: kehandalan, empati, dan jaminan sebagai variabel yang mendukung secara signifikan terhadap peningkatan kepuasan pedagang.

2. Karena variabel kehandalan yang dominan pengaruhnya terhadap kepuasan pedagang, maka disarankan untuk dipertahankan terutama indikator yang membentuknya. Sedangkan variabel ketanggapan dan tampilan fisik yang pengaruhnya tidak signifikan perlu mendapat perhatian khusus untuk dimaksimalkan pelaksanaannya terutama pada indikator pembentuknya demi menunjang peningkatan kepuasan pedagang di masa akan datang. 


\section{DAFTAR PUSTAKA}

Algifari, 2007. Analisis Regresi, BPFE, Yogyakarta.

Wahyuningsih, Anis, 2002. Analisa Tingkat Kepuasan Konsumen Berdasarkan Kualitas Pelayanan Pada Rumah Sakit Umum Kabupaten Karanganyar, Skripsi Fakultas Ekonomi Program Studi Manajemen UMS, Surakarta.

Aritonang, Lerbin R. Aritonang R. 2005. Kepuasan Pelanggan. Pengukuran dan Penganalisisan dengan SPSS. Gramedia Pustaka Utama, Jakarta.

Boeke, J. H, 1953. Economics and Economic Policy of Dual Societies: As Exemplified by Indonesia. N. V. Haarlem: HD Tjeenk Willink \& Zoon.

Djarwanto \& Subagyo, Pangestu, 2003. Statistik Induktif, BPFE, Yogyakarta.

Goetsch dan Davis, 1994

Handi, Irawan, 2002, Prinsip Kepuasan Pelanggan, Elekmedia Komputindo, Jakarta

Irawan, H. 2007. 10 Prinsip Kepuasan Pelanggan. Media Komputindo, Jakarta.

Junaedi, 2002. Analisis Kualitas Layanan Terhadap Kepuasan Nasabah Taplus BNI cabang Surakarta. Tesis tidak Dipublikasikan.

Kotler, Philip, 1997 Manajemen Pemasaran : Analisis, Perencanaan, Implementasi dan Pengendalian, Edisi Bahasa Indonesia Jilid 2, Jakarta, Salemba empat - Prentice Hall, hal 83-92.

---------. 2005. Manajemen Pemasaran. (Terjemahan). PT. INDEKS Kelompok Media, Jakarta.

Lupiyoadi, Rambat. 2001. Manajemen Pemasaran Jasa Teori dan Praktik. Jakarta : Salemba Empat.

Lovelock, C. And L.K. Wright. 2005. Manajemen Pemasaran Jasa (Terjemahan). Indeks, Jakarta.

Margaretha, 2003. Kualitas Pelayanan: Teori dan Aplikasi. Penerbit Mandar Maju, Jakarta.

Mariaty Silalahi, 2007. Analisis Pengaruh Kualitas Pelayanan terhadap Kepuasan Pasien di Rumah Sakit Islam Malahayati Medan. Tesis tidak Dipublikasikan.

Martul, Shadiqqin, 2004. Implementasi Dimensi Kualitas Pelayanan Pelanggan. Penerbit Sinar Grafika, Jakarta.

Masri, S. \& Effendi, Sofian, 2001. Metodologi Penelitian Survei, Pustaka LP3 ES, Jakarta. 
Mauludin, Hanif. 2001. Analisis Kualitas Pelayanan, Pengaruhnya Terhadap Image (Studi Pada Penderita Rawat Inap RSUD. DR. R. Koesma Tuban). Jurnal Penelitian Akuntansi, Bisnis dan Manajemen, Vol. 7, No. 1 (April) : 37-51

Parasuraman, A., Zeithalm, V., dan Berry L., 1990. SERVQUAL: A Multiple item Scale for Measuring Consumer Perceptions of Service Quality. Journal of Retaliling.

Rangkuti, F. 2003. Measuring Costumer Satisfaction. Gramedia Pustaka Utama. Jakarta.

Sastradipoera, Komaruddin, 2006. Pasar Sebagai Etalase Harga Diri”,, dalam Ajip Rosidi, dkk (eds). 2006. Prosiding Konferensi Internasional Budaya Sunda (Jilid 2). Yayasan Kebudayaan Rancage. Jakarta.

Samuelson, Jeniston, 2000. Application of Quality Service Theory. Published by John Wiley and Sons, USA.

Singgih, Santoso, 2002. SPSS Statistik Multivariat, Elek Media Komputindo, Jakarta.

Sugiyono, 2008. Statistik NonParametrik untuk Penelitian, Alfabeta, Bandung.

Suharsimi, A., 2003. Prosedur Penelitian Suatu Pendekatan Praktek, Rineka Cipta, Jakarta.

Sunyoto, Hamingpraja, 2004. Jaminan Kualitas Pelayanan Pelanggan. Penerbit Liberty, Yogyakarta.

Supranto, Johanes, 2007. Pengukuran Tingkat Kepuasan Pelanggan, Rineka Cipta, Jakarta.

Tjiptono, Fandi. 1997. Strategi Pemasaran, Penerbit Andi Yogyakarta.

1998. Strategi Bisnis dan Manajemen.Penerbit Andi, Yogyakarta.

Tjiptono, Fandy \& Anastasia Diana. (2003). Total Quality Management, Yogyakarta : Andi Offset, Yogyakarta.

Tjiptono, Fandy, 2003, Strategy Pemasaran, Penerbit : Andi offset, Yogyakarta.

Tjiptono, Fandy, 2004. Kepuasan Pelanggan dalam Pelayanan. Penerbit

Tjiptono, Fandy \& Anastasia Diana. (2003). Total Quality Management, Yogyakarta : Andi

Tjiptono, Fandy, 2003, Strategy Pemasaran, Penerbit : Andi offset, Yogyakarta.

Tjiptono, Fandy, 2004. Kepuasan Pelanggan dalam Pelayanan. Penerbit Andi. Yogyakarta. 
Tjiptono, Fandy dan Gregorius Chandra. 2005. Service Quality Satisfaction. Penerbit Andi, Yogyakarta.

Thabrani, Hasbullah, 2002, Asuransi Kesehatan di Indonesia, UI press, Jakarta

Thoha, Miftah, 2002. Perilaku Organisasi. Raja Grafindo, Persada, Jakarta.

Tse, David K. And Peter C Wilton, 1988. Models of Customer Satisfaction Formation : An Extension. Journal of Marketing Research Vol. 25, May 1988; p.204-212.

Wahyudi dan Ahmadi. 2003. Kasus Pasar Wonokromo Surabaya Cermin Buruknya Pengelolaanan Pasar. Artikel dalam Kompas, 24 Maret 2003.

Wijono, Djoko, 2001, Manajemen Mutu Pelayanan Kesehatan, Teori, Strategi dan Aplikasi, Vol.01, Airlangga University Press, Surabaya 